\title{
FAKTOR-FAKTOR YANG BERHUBUNGAN DENGAN PERILAKU SEKSUAL PRANIKAH REMAJA WANITA DAN PRIA DI INDONESIA
}

\author{
Nur Indah Kusuma Dewi dan Krisnawati Bantas \\ Universitas Indonesia, Depok, Jawa Barat, Indonesia \\ Email: nur.indah87@ui.ac.id dan krisnabantas@yahoo.com
}

\begin{tabular}{|c|c|}
\hline ARTIKEL INFO & $A B S T K$ \\
\hline $\begin{array}{l}\text { Tanggal diterima: } 5 \text { April2021 } \\
\text { Tanggal revisi: } 15 \text { April } 2021 \\
\text { Tanggal yang disetujui: } 25 \\
\text { April } 2021\end{array}$ & $\begin{array}{l}\text { This study used cross-sectional design (cut latitude). } \\
\text { Analysis used logistic regression. The results showed that } \\
\text { the factors that influenced the behavior of prenuptial sexual } \\
\text { relations were the age of respondents } 18-19 \text { years old had }\end{array}$ \\
\hline $\begin{array}{l}\text { Keywords: } \\
\text { adolescents; prenuptial sexual } \\
\text { intercourse; man; woman; } \\
\text { puberty }\end{array}$ & $\begin{array}{l}\text { a 2,787 chance (OR 2,787: } 95 \% \text { CI } 1,665-4,665) \text { to have } \\
\text { prenuptial sexual intercourse compared to adolescents with } \\
\text { the age of } 15-17 \text { years, teenage boys had a } 0.510 \text { chance } \\
\text { (OR 0.510: } 95 \% \text { CI } 0.341-0.764) \text { to have prenuptial } \\
\text { sexual intercourse compared to teenage girls, adolescents } \\
\text { with peer influence had a } 38,616 \text { chance (OR } 38,616: 95 \% \\
\text { CI 22,516-66,228). Conclusions From the results of this } \\
\text { study it is known that factors that are significantly related } \\
\text { to prenuptial sexual relations behavior in adolescent men } \\
\text { and women aged } 15-19 \text { years in Indonesia are the age of } \\
\text { respondents, gender, influence of peers, alcohol } \\
\text { consumption, adolescent attitudes towards the importance } \\
\text { of maintaining virginity, puberty age and risky behavior. } \\
\text { There was an interaction between the history of alcohol } \\
\text { consumption and the age of the respondent, alcohol } \\
\text { consumption with gender and the influence of peers on the } \\
\text { age of the respondent. }\end{array}$ \\
\hline
\end{tabular}

\begin{abstract}
ABSTRAK
Penelitian ini menggunakan desain cross-sectional (potong lintang). Analisis yang digunakan regresi logistik. Hasil penelitian menunjukkan faktor - faktor yang mempengaruhi perilaku hubungan seksual pranikah adalah usia responden 18 - 19 tahun berpeluang 2,787 kali (OR 2,787: 95\% CI 1,665 - 4,665) untuk melakukan hubungan seksual pranikah dibandingkan remaja dengan usia $15-17$ tahun, remaja pria berpeluang 0,510 kali (OR 0,510: 95\% CI 0,341 - 0,764) untuk melakukan hubungan seksual pranikah dibandingkan dengan remaja wanita, remaja dengan pengaruh teman sebaya berpeluang 38,616 kali (OR 38,616: 95\% CI 22,516 - 66,228). Kesimpulan dari hasil penelitian ini diketahui bahwa faktor-faktor yang secara signifikan berhubungan dengan perilaku hubungan seksual pranikah pada remaja pria dan wanita usia 15 - 19 tahun di Indonesia adalah usia responden, jenis kelamin, pengaruh teman sebaya, konsumsi alkohol, sikap remaja terhadap
\end{abstract}

\begin{tabular}{ll}
\hline How to cite: & Dewi, Nur Indah Kusuma, et. al. (2021) Faktor - Faktor Yang Berhubungan Dengan Perilaku Seksual \\
& Pranikah Remaja Wanita Dan Pria Di Indonesia. Jurnal Health Sains 2(4). \\
& http://jurnal.healthsains.co.id/index.php/jhs/article/view/155 \\
& $2723-6927$ \\
E-ISSN: & Ridwan Institute
\end{tabular}




\section{Kata Kunci:}

remaja; seks pranikah; pria;

wanita; pubertas pentingnya menjaga keperawanan, usia pubertas dan perilaku berisiko. Terdapat interaksi antara riwayat konsumsi alkohol dengan usia responden, konsumsi alkohol dengan jenis kelamin dan pengaruh teman sebaya terhadap usia responden.

\section{Pendahuluan}

Masa remaja adalah masa transisi dari masa anak-anak menuju dewasa. Terjadi berbagai perubahan pada masa remaja yaitu perubahan biologis, kognitif dan sosioemosional (Santrock JW., 2007). Hormon seksual pada masa remaja sudah mulai berfungsi. Hal tersebut mendorong remaja untuk melakukan berbagai jenis perilaku seksual (Kaplan HI, Benjamin JS, 2010). Batasan usia remaja yang umum digunakan oleh para ahli antara usia 12 hingga 21 tahun. Menurut Monks rentang waktu usia remaja ini biasanya dibedakan atas tiga, yaitu masa remaja awal (12 - 15 tahun), remaja pertengahan ( 15 - 18 tahun) dan remaja akhir (18 - 21 tahun). Menurut WHO, remaja adalah penduduk dalam rentang usia 10 -19 tahun (WHO, 2018)

Hasil Proyeksi Penduduk menunjukkan bahwa jumlah penduduk usia remaja ini akan mengalami peningkatan hingga tahun 2030 (Badan Pusat Statistik \& UNICEF, 2016). Jumlah remaja yang cukup besar ini bisa menjadi tantangan yang berat bagi pemerintah, terutama berkaitan dengan pengembangan dan pelaksanaan program kesehatan reproduksi (Hidayat, 2005). Kegiatan seksual yang tidak bertanggung jawab menempatkan remaja pada tantangan risiko terhadap berbagai masalah kesehatan reproduksi (Reproductive Health: Teen Pregnancy., 2008). Remaja yang kurang mampu beradaptasi dengan perubahan fisik dan hormonal akan memperlihatkan perilaku berisiko (Mc. Murray., 2013).

Perilaku seksual merupakan perilaku berisiko, yaitu segala tingkah laku seksual yang didorong oleh hasrat seksual dengan lawan jenisnya. Bentuk-bentuk perilaku ini umumnya bertahap dimulai dari tingkat yang kurang intim sampai dengan hubungan seksual (Soetjiningsih, 2008). Presentase wanita usia 15-24 tahun yang belum kawin dan pernah melakukan hubungan seksual pranikah dari tahun 2012 sampai tahun 2017 mengalami peningkatan, sedangkan presentase pria yang melakukan hubungan seksual pranikah dari tahun 2012 sampai 2017 menurun. Pada tahun 2012 wanita usia 15-19 tahun sebanyak 0.7\%, dan usia 20-24 tahun sebanyak 1,6 \%, sedangkan pada lakilaki usia 15-19 tahun sebanyak 4,5\% dan usia 20-24 tahun sebanyak 14,6\% (BKKBN, 2012). Pada tahun 2017 wanita usia 15-19 tahun sebanyak 0.9\%, dan usia 20-24 tahun sebanyak 2,6\%, sedangkan pada laki-laki usia 15-19 tahun sebanyak 3,6\% dan usia 20-24 tahun sebanyak 14,0\% (BKKBN, 2017).

Banyaknya kasus yang terjadi di kalangan remaja menunjukan bahwa remaja saat ini perlu perhatian penting dari berbagai pihak. Angka aktivitas seksual yang terus meningkat semakin menjadi ancaman negara dalam menghadapi bonus demografi. Untuk itu perlu dilakukannya penelitian untuk mengetahui hal-hal yang berkaitan dengan perilaku seksual pada remaja khususnya faktor-faktor yang mempengaruhi hubungan seksual pranikah pada remaja.

\section{Metode Penelitian}

Penelitian ini merupakan penelitian kuantitatif yang dilakukan dengan menggunakan data SDKI-KRR tahun 2017 yang merupakan survei berskala nasional meliputi seluruh wilayah Indonesia. Lokasi penelitian dilakukan pada 34 provinsi di Indonesia pada bulan Juli- September 2017.

Populasi sumber pada penelitian ini adalah seluruh remaja wanita dan pria usia 15 - 19 tahun yang terpilih menjadi sampel 
penelitian dalam survey SDKI-KRR 2017. Populasi eligible adalah terdiri dari populasi sumber yang memenuhi kriteria inklusi dan eksklusi. Kriteria inklusi dalam penelitian ini adalah semua responen remaja pria dan wanita yang berusia $15-19$ tahun yang belum menikah, sudah mengalami masa pubertas, serta sedangkan untuk kriteria eksklusinya adalah responden dengan ketidak lengkapan data. Jumlah sampel yang dapat dianalisis 14.501 responden.

Variabel dependen dalam penelitian ini adalah perilaku hubungan seksual pranikah yang diukur berdasarkan ya atau tidak nya responden melakukan hubungan kelamin antara remaja pria dan wanita yang belum menikah layaknya suami istri dan terjadi penetrasi (masuknya alat kelamin pria ke dalam alat kelamin wanita). Jawaban ya jika responden menjawab pernah melakukan hubungan seksual pranikah. Sedangkan jawaban tidak jika responden menjawab belum pernah melakukan hubungan seksual pranikah. Alat ukur menggunakan kuesioner SDKI 17 WUS nomor 1705 dan RP nomor 705.

Variabel independen meliputi: variabel tempat tinggal yang diukur berdasarkan penggolongan unit wilayah administrasi yang terkecil yaitu desa/ kelurahan dan perkotaan dimana tempat responden tinggal (UU RI No. 26 tahun 2007 Tentang Penataan ruang) yang dikategorikan menjadi 2 kategori (pedesaan dan perkotaan). Alat ukur yang digunakan kuesioner SDKI 17 WUS nomor 5 dan RP nomor 5; variabel tingkat pendidikan diukur berdasarkan jenjang pendidikan formal yang pernah atau sedang diikuti responden, dibagi menjadi tiga kategori (rendah, sedang dan tinggi). Alat ukur yang digunakan kuesioner SDKI 17 WUS nomor 108 dan RP nomor 109; variabel jenis kelamin yang diukur berdasarkan ciri seksual yang dimiliki responden secara biologis sejak dilahirkan, yang dibagi menjadi dua kategori (pria dan wanita). Alat ukur yang digunakan kuesioner SDKI 17 WUS dan $\mathrm{RP}$; variabel usia responden diukur berdasarkan lama waktu hidup responden atau sejak dilahirkan dengan dua kategori $(15-17$ tahun dan 18 - 19 tahun). Alat ukur yang digunakan SDKI 17 WUS nomor 106 dan RP nomor 107; variabel usia pubertas diukur berdasarkan usia pertama kali responden mengalami menstruasi atau mimpi basah yang dibagi menjadi 2 kategori $(<15$ tahun dan $\geq$ 15 tahun) Alat ukur yang digunakan kuesioner SDKI 17 WUS nomor 1305 dan RP nomor 205; variabel pengaruh teman sebaya diukur berdasarkan jawaban responden ya atau tidak adanya dorongan dalam berperilaku seksual yang muncul akibat memiliki teman yang telah melakukan hubungan seksual pranikah. Jawaban ya jika responden memiliki teman yang pernah melakukan hubugan seksual pranikah dan merasa terdorong untuk melaukannya. Alat ukur yang digunakan kuesioner SDKI 17 WUS nomor 1712, 1713 dan RP 715, 716 ; variabel riwayat konsumsi alkohol diukur berdasarkan jawaban responden pernah atau tidak pernah mengkonsumsi minum minuman beralkohol dalam waktu 3 bulan terakhir walaupun hanya satu atau dua teguk yang. Alat ukur yang digunakan kuesioner SDKI 17 WUS nomor 1607 dan RP nomor 510; variabel pengetahuan tentang risiko kehamilan diukur berdasarkan baik atau buruknya kemampuan remaja dalam menjawab pertanyaan tentang risiko terjadinya kehamilan dikarenakan melakukan hubungan seksual satu kali. Pengetahuan buruk apabila jawabannya salah sedangkan pengetahuannya baik jika jawabannya benar. Alat ukur yang digunakan kuesioner SDKI 17 WUS nomor1309 dan RP nomor 211; variabel sikap remaja terhadap pentingnya menjaga keperawanan diukur berdasarkan pendapat atau penilaian remaja mengenai penting atau tidaknya seorang remaja untuk tidak melakukan hubungan seksual sebelum menikah yang dibagi menjadi dua kategori (positif dan negatif). 
Sikap negatif jika jawabannya tidak setuju untuk menjaga keperawanan sebelum menikah sedangkan sikap positif jika jawabannya setuju untuk menjaga keperawaann sebelum menikah. Alat ukur yang digunakan kuesioner SDKI 17 WUS nomor 1718 dan RP nomor 721; variabel perilaku berisiko diukur berdasarkan aktivitas yang pernah dilakukan selama berhubungan dengan lawan jenis/ pacar seperti berpegangan tangan, berpelukan, cium bibir, merasa diraba yang dibagi menjadi dua kategorik (berisiko dan tidak berisiko). Perilaku berisiko jika pernah melakukan ciuman bibir, dan atau meraba dan diraba sedangkan perilaku tidak berisiko jika tidak melakukan ciuman bibir, dan atau meraba atau diraba dan atau tidak berpacaran. Alat ukur yang digunakan kuesioner SDKI 17 WUS nomor 1702, 1703, 1704 dan RP 702, 703, 704.

Penelitian ini menggunakan desain cross-sectional (potong lintang). Pengolahan data dilakukan dengan menggunakan software statistik SPSS 2.4 di Laboratorium komputer FKM UI. Analsis data dilakukan dengan tahapan analisis univariat, bivariat dan multivariat. Pada analisis univariat untuk melihat distribusi frekuensi dari variabel independen dan dependen. Sedangkan analisis bivariat menggunakan uji regresi logistik sederhana dan analisis multivariat menggunakan uji regresi logistik berganda.

\section{Hasil dan Pembahasan}

\section{A. Hasil penelitian}

1. Analisis Univariat

Tabel 1

Distribusi frekuensi perilaku hubungan seksual pranikah pada remaja usia 15 - 19 tahun di

Indonesia tahun 2017

\begin{tabular}{ccc}
$\begin{array}{c}\text { Perilaku } \\
\text { hubungan } \\
\text { seksual pranikah }\end{array}$ & $\mathrm{N}$ & $\%$ \\
\cline { 1 - 1 } Ya & $\mathbf{4 7 8}$ & $\mathbf{3 , 3}$ \\
\hline Tidak & $\mathbf{1 4 0 2 3}$ & $\mathbf{9 6 , 7}$ \\
\hline
\end{tabular}

\begin{tabular}{lll}
\hline Total & $\mathbf{1 4 5 0 1}$ & 100 \\
\hline
\end{tabular}

Berdasarkan tabel 1. Didapatkan bahwa $478(3,3 \%)$ remaja wanita dan pria usia $15-19$ tahun pernah melakukan hubungan seksual pranikah dan sebanyak 14023 (96,7\%) tidak melakukan hubungan seksual pranikah.

\section{Tabel 2}

Distribusi frekuensi remaja pria dan wanita yang pernah melakukan perilaku hubungan seksual pranikah di Indonesia tahun 2017

\begin{tabular}{ccc}
\hline Jenis kelamin & N & $\%$ \\
\hline Pria & 391 & $\mathbf{8 1 , 8}$ \\
\hline Wanita & 87 & 18,2 \\
\hline Total & 478 & 100 \\
\hline
\end{tabular}

Berdasarkan tabel 2. Didapatkan bahwa remaja pria yang pernah melakukan hubungan seksual pranikah sebanyak $391 \quad(81,8 \%)$ sedangkan remaja wanita yang pernah melakukan hubungan seksual pranikah sebanyak $87(18,2 \%)$.

Tabel 3

Distribusi frekuensi karakteristik responden berdasarkan usia responden, pendidikan, tempat tinggal, jenis kelamin, pengaruh teman sebaya, konsumsi alkohol,pengetahuan tentang risiko kehamilan, pentingnya menjaga keperawanan, usia pubertas dan perilaku berisiko pada remaja wanita dan pria usia 15 - 19 tahun di

\begin{tabular}{lcc}
\multicolumn{3}{c}{ Indonesia } \\
\hline Karakteristik Responden & $\mathrm{N}$ & $\%$ \\
\hline Usia Responden & & \\
18 - 19 tahun & $\mathbf{4 8 7 2}$ & $\mathbf{3 3 , 6}$ \\
$\mathbf{1 5}-\mathbf{1 7}$ tahun & $\mathbf{9 6 2 9}$ & $\mathbf{6 6 , 4}$ \\
\hline Tingkat Pendidikan & & \\
Pendidikan Rendah & $\mathbf{2 9 6 1}$ & $\mathbf{2 0 , 4}$ \\
Pendidikan Menengah & $\mathbf{1 0 1 9 1}$ & $\mathbf{7 0 , 3}$ \\
Pendidikan Tinggi & $\mathbf{1 3 4 9}$ & $\mathbf{9 , 3}$ \\
\hline Tempat Tinggal & & \\
Pedesaan & $\mathbf{6 4 2 0}$ & $\mathbf{4 4 , 3}$ \\
Perkotaan & $\mathbf{8 0 8 1}$ & $\mathbf{5 5 , 7}$ \\
\hline Jenis Kelamin & & \\
Pria & $\mathbf{7 3 3 0}$ & $\mathbf{5 0 , 5}$ \\
Wanita & $\mathbf{7 1 7 1}$ & $\mathbf{4 9 , 5}$ \\
\hline
\end{tabular}




\begin{tabular}{|c|c|c|}
\hline $\begin{array}{l}\text { Pengaruh teman sebaya } \\
\text { Ya } \\
\text { Tidak }\end{array}$ & $\begin{array}{r}2969 \\
11532 \\
\end{array}$ & $\begin{array}{l}20,5 \\
79,5\end{array}$ \\
\hline $\begin{array}{l}\text { Konsumsi alkohol } \\
\text { Ya } \\
\text { Tidak }\end{array}$ & $\begin{array}{r}2708 \\
11793\end{array}$ & $\begin{array}{l}18,7 \\
81,3\end{array}$ \\
\hline $\begin{array}{l}\text { Pengetahuan tentang risiko } \\
\text { kehamilan } \\
\text { Buruk } \\
\text { Baik } \\
\end{array}$ & $\begin{array}{l}7423 \\
7078\end{array}$ & $\begin{array}{l}51,2 \\
48,8\end{array}$ \\
\hline $\begin{array}{l}\text { Sikap remaja terhadap } \\
\text { pentingnya menjaga } \\
\text { keperawanan } \\
\text { Negatif } \\
\text { Positif }\end{array}$ & $\begin{array}{c}168 \\
14333\end{array}$ & $\begin{array}{c}1,2 \\
\mathbf{9 8 , 8}\end{array}$ \\
\hline $\begin{array}{l}\text { Usia pubertas } \\
<15 \text { tahun } \\
\geq 15 \text { tahun }\end{array}$ & $\begin{array}{c}10574 \\
3927\end{array}$ & $\begin{array}{l}72,9 \\
27,1\end{array}$ \\
\hline $\begin{array}{l}\text { Perilaku berisiko } \\
\text { Ya } \\
\text { Tidak }\end{array}$ & $\begin{array}{l}8904 \\
5597\end{array}$ & $\begin{array}{l}61,4 \\
38,6\end{array}$ \\
\hline
\end{tabular}

Berdasarkan tabel 3. Jika dilihat berdasarkan kelompok usia ada sebanyak $9629 \quad(66,4 \%)$ responden yang berusia $15-17$ tahun dan sebanyak $4872 \quad(33,6 \%)$ responden yang berusia 18 - 19 tahun. Responden yang memiliki pendidikan tinggi yaitu $1349(9,3 \%)$, responden yang memiliki pendidikan menengah paling banyak yaitu $10191 \quad(70,3 \%)$ sedangkan responden yang memiliki pendidikan rendah 2916 orang $(20,1 \%)$. Berdasarkan tempat tinggal, ada sebanyak $6420 \quad(44,3 \%)$ responden yang tinggal di pedesaan dan yang tinggal di perkotaan ada sebanyak 8081 (55,7\%). Paling banyak responden adalah remaja pria yaitu 7330 orang (50,5\%) sedangkan responden remaja perempuan hanya 7171 orang $(49,5 \%)$. Berdasarakan pengaruh teman sebaya ada sebanyak $11532 \quad(79,5 \%)$ responden tidak terpengaruh dengan teman sebayanya dan sisanya 2969 $(20,5 \%)$ responden terpengaruh teman sebayanya yang sudah pernah melakukan hubungan seksual pranikah. Remaja yang mengkonsumsi alkohol sebanyak 2708 orang $(18,7 \%)$ sedangkan remaja yang tidak mengkonsumsi alkohol sebanyak 11793 orang $(81,3 \%)$. Berdasarkan pengetahuan tentang resiko kehamilan, ada sebanyak $7423(51,2 \%)$ responden yang berpengetahuan buruk dan 7078
$(48,8 \%) \quad$ responden yang berpengetahuan baik. Banyak responden remaja yang berpendapat bahwa menjaga keperawanan penting $14333(98,8 \%)$ sisanya sebanyak 168 $(1,2 \%)$ responden berpendapat bahwa menjaga keperawanan sebelum menikah tidaklah penting. Berdasarkan usia pubertas, responden yang mengalami usia pubertas <15 tahun sebnayak $10574 \quad(72,9 \%)$ dan yang mengalami usia pubertas $\geq 15$ tahun sebanyak 3927 ( 27,1\%). Berdasarkan perilaku berisiko ada sebanyak 8904 $(61,4 \%)$ responden yang beresiko dalam berperilaku, dan sisanya yang tidak berisiko sebanyak 5597 (38,6\%).

2. Analisis Bivariat

\section{Tabel 4}

Faktor - Faktor yang Berhubungan dengan Perilaku Hubungan Seksual Pranikah Pada Remaja Wanita dan Pria Usia 15 - 19 Tahun Analisis lanjut data SDKI tahun 2017

\begin{tabular}{|c|c|c|c|c|c|c|c|}
\hline \multirow{3}{*}{ Variabel } & \multicolumn{4}{|c|}{$\begin{array}{l}\text { Perilaku Hubungan Seksual } \\
\text { Pranikah }\end{array}$} & \multirow{3}{*}{ OR } & \multirow{3}{*}{$\begin{array}{r}95 \% \\
\text { CI }\end{array}$} & \multirow{3}{*}{$\begin{array}{c}P{ }^{P} \bar{u} u \\
e\end{array}$} \\
\hline & \multicolumn{2}{|c|}{$\mathrm{Ya}$} & \multicolumn{2}{|c|}{ Tidak } & & & \\
\hline & $\mathrm{N}$ & $\%$ & $\mathbf{N}$ & $\%$ & & & \\
\hline & 290 & 60,7 & 4582 & 32,7 & 1,919 & 1,551 & $\mathbf{0 , 0 0 0}$ \\
\hline $15-17$ tahun & 188 & 39,3 & 9441 & 67,3 & 1 & - & \\
\hline \multirow{2}{*}{\multicolumn{8}{|c|}{$\begin{array}{l}\text { Tingkat } \\
\text { Pendidikan }\end{array}$}} \\
\hline & & & & & & & \\
\hline $\begin{array}{l}\text { Pendidikan } \\
\text { Rendah }\end{array}$ & 164 & 34,5 & 2752 & 19,7 & 2,340 & 1,329 & 0,000 \\
\hline Menengah & 274 & 57,6 & 9917 & 70,9 & 1,294 & - & 0,18 \\
\hline \multirow[t]{3}{*}{ Tinggi } & 38 & 8,0 & 1311 & 9,4 & 1 & 4,201 & \\
\hline & & & & & & 1,622 & \\
\hline & & & & & & 2,954 & \\
\hline \multicolumn{7}{|l|}{ Tempat Tinggal } & \\
\hline \multirow{3}{*}{$\begin{array}{l}\text { Pedesaan } \\
\text { Perkotaan }\end{array}$} & 246 & 51,5 & 6174 & 44,0 & 1,115 & 0,910 & 0,293 \\
\hline & 232 & 48,5 & 784 & 56,0 & 1 & - & \\
\hline \multirow{2}{*}{\multicolumn{8}{|c|}{ Jenis Kelamin }} \\
\hline & & & & & & & \\
\hline \multirow[b]{2}{*}{$\begin{array}{l}\text { Pria } \\
\text { Wanita }\end{array}$} & 391 & 81,8 & 6939 & 49,5 & 0,359 & & 0,000 \\
\hline & 87 & 18,2 & 708 & 50,5 & 1 & - & \\
\hline \multicolumn{8}{|l|}{$\begin{array}{l}\text { Pengaruh } \\
\text { teman sebaya }\end{array}$} \\
\hline \multirow{3}{*}{ Tidak } & 411 & 86,0 & 2558 & 18,2 & 20,531 & & 0,00 \\
\hline & 67 & 14,0 & 114 & 81,8 & 1 & $3-$ & \\
\hline & & & & & & $\begin{array}{l}30,29 \\
7\end{array}$ & \\
\hline \multicolumn{8}{|l|}{ Konsumsi } \\
\hline \multirow{3}{*}{$\begin{array}{l}\text { alkohol } \\
\text { Ya } \\
\text { Tidak }\end{array}$} & & & 2359 & 16,8 & 1,583 & & 0,00 \\
\hline & 129 & 27,0 & 116 & 83,2 & 1 & - & 2 \\
\hline & & & 4 & & & 2,130 & \\
\hline \multicolumn{8}{|l|}{$\begin{array}{l}\text { Pengetahuan } \\
\text { tentang risiko }\end{array}$} \\
\hline & 255 & 53,3 & 7168 & 51,1 & 1,073 & & 0,49 \\
\hline \multirow{2}{*}{$\begin{array}{l}\text { Buruk } \\
\text { Baik }\end{array}$} & 223 & 46,7 & 685 & 48,9 & 1 & - & 3 \\
\hline & & & 5 & & & 1,312 & \\
\hline $\begin{array}{l}\text { Sikap remaja } \\
\text { terhadap }\end{array}$ & 42 & 8.8 & 126 & 09 & 6.538 & 4,128 & 0.00 \\
\hline \multirow{4}{*}{$\begin{array}{l}\text { pentingnya } \\
\text { menjaga } \\
\text { keperawanan } \\
\text { Negatif }\end{array}$} & 436 & $\begin{array}{l}\mathbf{8 , 0} \\
\mathbf{9 1 , 2}\end{array}$ & 13897 & 99,1 & 1 & & 0 \\
\hline & & & & & & 10,35 & \\
\hline & & & & & & 6 & \\
\hline & & & & & & & \\
\hline \multicolumn{8}{|l|}{ Positif } \\
\hline \multicolumn{8}{|l|}{ Usia Pubertas } \\
\hline$<15$ tahun & 249 & 52,1 & 10325 & 73,6 & 0,745 & 0,603 & $\mathbf{0 , 0 0}$ \\
\hline$\geq 15$ tahun & 229 & 47,9 & 3698 & 26,4 & 1 & - & 7 \\
\hline
\end{tabular}




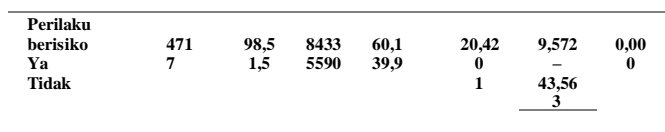

Berdasarkan tabel 3 hasil penelitian menunjukkan bahwa faktor faktor yang berpengaruh signifikan secara statistik terhadap perilaku hubungan seksual pranikah pada remaja adalah usia responden, tingkat pendidikan, jenis kelamin, pengaruh teman sebaya, konsumsi alkohol, sikap remaja terhadap pentingnya menjaga

keperawanan, usia pubertas dan perilaku berisiko (p-value $<0,05)$. Berdasarkan tabel diatas, ada beberapa variabel independen yang menghasilkan p-value $<0,25$ yaitu usia responden, tingkat pendidikan, jenis kelamin, pengaruh teman sebaya, konsumsi alkohol, sikap remaja terhadap pentingnya menjaga keperawanan, usia pubertas dan perilaku berisiko sehingga seluruh variabel tersebut memenuhi syarat untuk dimasukkan dalam permodelan multivariate.

3. Analisis Multivariat

Tabel 5

Pemodelan Akhir Multivariat Faktor - Faktor yang Mempengaruhi

Perilaku Hubungan Seksual Pranikah pada Remaja Wanita dan Pria Usia 15 - 19 Tahun Analisis lanjut data SDKI

\begin{tabular}{|c|c|c|c|c|}
\hline Variabel & B & $\begin{array}{c}\text { p- } \\
\text { value }\end{array}$ & POR & $95 \% \mathrm{CI}$ \\
\hline $\begin{array}{l}\text { Usia Responden } \\
18-19 \text { tahun } \\
15-17 \text { tahun }\end{array}$ & 1,025 & 0,000 & $\begin{array}{c}2,787 \\
1\end{array}$ & $1,665-4,665$ \\
\hline $\begin{array}{l}\text { Jenis Kelamin } \\
\text { Pria } \\
\text { Wanita }\end{array}$ & $-0,673$ & 0,001 & $\begin{array}{c}0,510 \\
1\end{array}$ & $0,341-0,764$ \\
\hline $\begin{array}{l}\text { Pengaruh teman } \\
\text { sebaya } \\
\text { Ya } \\
\text { Tidak } \\
\end{array}$ & 3,654 & $\mathbf{0 , 0 0 0}$ & $\begin{array}{c}38,616 \\
1\end{array}$ & $22,516-66,228$ \\
\hline $\begin{array}{l}\text { Konsumsi } \\
\text { alkohol } \\
\text { Ya } \\
\text { Tidak }\end{array}$ & 0,950 & 0,004 & $\begin{array}{c}2,586 \\
1\end{array}$ & $2,586-1,359$ \\
\hline $\begin{array}{l}\text { Sikap remaja } \\
\text { terhadap } \\
\text { pentingnya } \\
\text { menjaga } \\
\text { keperawanan }\end{array}$ & 1,949 & 0,000 & $\begin{array}{c}7,020 \\
1\end{array}$ & $4,437-11,106$ \\
\hline
\end{tabular}

\begin{tabular}{|c|c|c|c|c|}
\hline $\begin{array}{l}\text { Tidak } \\
\text { Ya }\end{array}$ & & & & \\
\hline $\begin{array}{l}\text { Usia Pubertas } \\
<15 \text { tahun } \\
\geq 15 \text { tahun }\end{array}$ & $-0,328$ & 0,002 & $\begin{array}{c}0,721 \\
1\end{array}$ & $0,585-0,888$ \\
\hline $\begin{array}{l}\text { Perilaku berisiko } \\
\text { Ya } \\
\text { Tidak }\end{array}$ & 2,875 & 0,000 & $\begin{array}{c}17,734 \\
1\end{array}$ & $8,330-37,751$ \\
\hline $\begin{array}{l}\text { Konsumsi } \\
\text { Alkohol*Usia } \\
\text { responden }\end{array}$ & 0,674 & 0,012 & 1,963 & $1,157-3,330$ \\
\hline $\begin{array}{l}\text { Konsum } \\
\text { si } \\
\text { Alkohol } \\
\text { *Jenis } \\
\text { Kelamin }\end{array}$ & $-1,012$ & 0,001 & 0,364 & $0,195-0,679$ \\
\hline $\begin{array}{l}\text { Usia } \\
\text { Responden } \\
\text { *Pengaruh } \\
\text { teman } \\
\text { sebaya }\end{array}$ & -1.105 & 0,001 & $\mathbf{0 , 3 3 1}$ & $0,170-0,644$ \\
\hline
\end{tabular}

OR adj untuk hubungan antara riwayat konsumsi alkohol dengan kejadian hubungan seksual pranikah pada remaja dengan usia 18 - 19 tahun dibagi dengan OR adj untuk hubungan antara riwayat konsumsi alkohol dengan kejadian hubungan sex pra nikah pada remaja usia 15 - 17 tahun adalah 1,963 kali. Jadi pada strata usia 18- 19 tahun hubungan riwayat konsumsi alkohol dengan kejadian hubungan seks pranikah lebih tinggi OR nya dibandingkan dengan strata usia 15 - 17 tahun.

OR adj untuk hubungan antara riwayat konsumsi alkohol dengan kejadian hubungan seksual pranikah pada pria dibagi dengan OR adj untuk hubungan antara riwayat konsumsi alkohol dengan kejadian hubungan sex pra nikah pada wanita adalah 0.364 kali. Jadi pada strata pria hubungan riwayat konsumsi alkohol dengan kejadian hubungan sex pranikah lebih rendah OR nya dibanding pada strata wanita.

$$
\text { OR adj untuk usia } 18-19
$$

tahun dengan pengaruh teman sebaya dibagi dengan OR adj untuk usia 15 17 tahun dengan pengaruh teman sebaya adalah 0.331 kali. Jadi pada strata usia 18 - 19 tahun dengan kejadian hubungan sex pranikah lebih 
rendah OR nya dibanding pada strata usia 15 - 17 tahun.

\section{Tabel 6}

Hasil Perhitungan OR Interaksi Variabel Konsumsi Alkohol dengan

\begin{tabular}{ccc}
\multicolumn{3}{c}{ Usia Responden } \\
\hline Variabel & Perhitungan & OR \\
& & \\
\hline Konsumsi Alkohol (1), & Exp $[0,950(1)+1,025(1)+$ & 14,14 \\
Usia Responden (1) & $0,674(1 \times 1)]$ \\
& & \\
\hline Konsumsi Alkohol (1), & Exp $[0,950(1)+1,025(0)+$ & 2,586 \\
Usia Responden (0) & $0,674(1 \times 0)]$ \\
& \\
\hline Konsumsi Alkohol (0), & Exp $[0,950(0)+1,025(1)+$ & 2,788 \\
Usia Responden (1) & $0,674(0 x 1)]$ \\
& \\
\hline Konsumsi Alkohol (0), & Exp $[0,950(0)+1,025(0)+$ \\
Usia Responden (0) & $0,674(0 x 0)]$ & 1 \\
&
\end{tabular}

Setelah perhitungan OR interaksi menunjukkan bahwa remaja yang mengkonsumsi alkohol dan berusia 18 - 19 tahun memiliki risiko 14,14 kali untuk melakukan hubungan seksual pranikah dibandingkan dengan remaja yang tidak mengkonsumsi alkohol dan berusia 15 - 17. Remaja yang mengkonsumsi alkohol dan berusia 15 - 17 tahun memiliki risiko 2,586 kali untuk melakukan hubungan seksual pranikah dibandingkan dengan remaja yang tidak mengkonsumsi alkohol dan berusia 15 - 17. Remaja yang tidak mengkonsumsi alkohol dan berusia 18 - 19 tahun memiliki risiko 0,510 kali untuk melakukan hubungan seksual pranikah dibandingkan dengan remaja yang tidak mengkonsumsi alkohol dan berusia $15-17$.

Tabel 7

\section{Hasil Perhitungan OR Interaksi} Variabel Konsumsi Alkohol dengan Jenis Kelamin

\begin{tabular}{ccc}
\hline Variabel & Perhitungan & OR \\
\hline Konsumsi Alkohol (1), & Exp $[0,950(1)+(-0,673)(1)+(-$ & $\mathbf{0 , 4 8 0}$ \\
Jenis Kelamin (1) & $1,012)(1 \times 1)]$ & \\
& \\
\hline Konsumsi Alkohol (1), & Exp $[0,950(1)+(-0,673)(0)+(-$ & $\mathbf{2 , 5 8 8}$
\end{tabular}

\begin{tabular}{ccc}
\hline Jenis Kelamin $(0)$ & $1,012)(1 \times 0)]$ & \\
\hline Konsumsi Alkohol $(0)$, & $\operatorname{Exp}[0,950(0)+(-0,673)(1)+(-$ & 0,510 \\
Jenis Kelamin $(1)$ & $1,012)(0 \times 1)]$ & \\
& & 1 \\
\hline Konsumsi Alkohol $(0)$, & $\operatorname{Exp}[0,950(0)+(-0,673)(0)+(-$ & \\
Jenis Kelamin $(0)$ & $1,012)(0 \times 0)]$ & \\
& \\
\hline
\end{tabular}

Setelah perhitungan OR interaksi menunjukkan bahwa remaja yang mengkonsumsi alkohol dan berjenis kelamin pria memiliki risiko 0,48 kali untuk melakukan hubungan seksual pranikah dibandingkan dengan remaja yang tidak mengkonsumsi alkohol dan berjenis kelamin perempuan. Remaja yang mengkonsumsi alkohol dan berjenis kelamin perempuan memiliki risiko 2,588 kali untuk melakukan hubungan seksual pranikah dibandingkan dengan remaja yang tidak mengkonsumsi alkohol dan berjenis kelamin perempuan. Remaja yang tidak mengkonsumsi alkohol dan berjenis kelamin pria memiliki risiko 0,510 kali untuk melakukan hubungan seksual pranikah dibandingkan dengan remaja yang tidak mengkonsumsi alkohol dan berjenis kelamin perempuan.

Tabel 8

Hasil Perhitungan Interaksi Tabel Variabel Usia Responden dengan Pengaruh Teman Sebaya

\begin{tabular}{|c|c|c|}
\hline Variabel & Perhitungan & OR \\
\hline $\begin{array}{l}\text { Usia Responden (1), } \\
\text { Pengaruh teman (1) }\end{array}$ & $\begin{array}{c}\operatorname{Exp}[1,025(1)+3,654(1)+(- \\
1,105)(1 \times 1)]\end{array}$ & 35,66 \\
\hline $\begin{array}{l}\text { Usia Responden (1), } \\
\text { Pengaruh Teman (0) }\end{array}$ & $\begin{array}{c}\operatorname{Exp}[1,025(1)+3,654(0)+(- \\
1,105)(1 \times 0)]\end{array}$ & 2,788 \\
\hline $\begin{array}{l}\text { Usia Responden (0), } \\
\text { Pengaruh Teman (1) }\end{array}$ & $\begin{array}{c}\operatorname{Exp}[1,025(0)+3,654(1)+(- \\
1,105)(0 x 1)]\end{array}$ & 38,62 \\
\hline $\begin{array}{l}\text { Usia Responden (0), } \\
\text { Pengaruh Teman (0) }\end{array}$ & $\begin{array}{c}\operatorname{Exp}[1,025(0)+3,654(0)+(- \\
1,105)(0 x 0)]\end{array}$ & 1 \\
\hline
\end{tabular}

Setelah perhitungan OR interaksi menunjukkan bahwa remaja dengan usia 18 - 19 tahun dan terpengaruh 
teman sebaya memiliki risiko 35,66 kali untuk melakukan hubungan seksual pranikah dibandingkan dengan remaja usia 15 - 17 tahun dan tidak terpengaruh oleh teman sebaya. Remaja dengan usia 18 - 19 tahun dan tidak terpengaruh oleh teman sebaya memiliki risiko2,788 kali untuk melakukan hubungan seksual pranikah dibandingkan dengan remaja usia 15 17 tahun dan tidak terpengaruh oleh teman sebaya. Remaja dengan usia 15 - 17 tahun dan terpengaruh oleh teman sebaya memiliki risiko 38,62 kali untuk melakukan hubungan seksual pranikah dibandingkan dengan remaja usia 15 17 tahun dan tidak terpengaruh oleh teman sebaya.

\section{B. Pembahasan}

Penelitian ini menggunakan data SDKI tahun 2017 pada komponen KRR. Beberapa pertanyaan yang diajukan merupakan pertanyaan sensitif sehingga terdapat kemungkinan responden menjawab tidak jujur. Penelitian ini bertujuan untuk mengetahui faktor - faktor yang mempengaruhi remaja untuk melakukan hubungan seksual pranikah pada remaja usia $15-19$ tahun di Indoensia dengan menggunakan desain cross sectional dimana mengukur eksposure dan outcome dilakukan pada waktu yang bersamaan sehingga memungkinkan terjadi recall bias. Kelemahan menggunakan data ini variabel - variabel yang diambil menyesuaikan dengan data yang tersedia.

Berdasarkan hasil penelitian didapatkan bahwa terdapat hubungan signifikan secara statistika antara usia responden dengan perilaku hubungan seksual pranikah. Remaja dengan usia 18 19 tahun 2,787 kali (OR 2,787: 95\% CI 1,665 - 4,665) lebih besar untuk melakukan hubungan seksual dibandingkan remaja dengan usia $15-17$ tahun. Hal ini dikarenakan semakin tua usia remaja maka akan semakin melepaskan dirinya dari orang tua dan akan berpindah bergaul dengan teman sebayanya. Menurut penelitian (Rusmiati \& Hastono, 2015) semakin bertambah usia remaja, semakin berkembang organ reproduksinya sehingga berpengaruh terhadap dorongan seksual yang dapat muncul dalam bentuk ketertarikan terhadap lawan jenis dan keinginan untuk mendapatkan kepuasan seksual.

Penelitian ini menunjukkan bahwa terdapat hubungan signifikan secara statistika antara jenis kelamin dengan perilaku hubungan seksual pranikah. Remaja pria berpeluang 0,51 kali (OR 0,510: $95 \%$ CI 0,341 - 0,764) melakukan hubungan seksual pranikah dibandingkan wanita. Hasil penelitian ini berbeda dengan penelitian yang menyatakan bahwa remaja pria lebih mungkin untuk melakukan hubungan seksual pranikah dibandingkan remaja perempuan (Rizkianti et al., 2020). Penelitian tersebut sejalan dengan penelitian (Nursal, 2008) remaja pria mempunyai peluang berperilaku seksual berisiko berat sebesar 4,41 kali dibandingkan dengan remaja wanita $(95 \% \mathrm{CI}=2,48-8,81)$. Secara sosial, anak laki - laki cenderung lebih bebas dibandingkan anak perempuan dan orang tua cenderung lebih proktektif terhadap anak perempuan.

Berdasarkan hasil penelitian ini, terdapat hubungan signifikan secara statistika antara pengaruh teman sebaya dengan perilaku hubungan seksual pranikah. Kelompok sebaya memiliki peran penting bagi remaja, oleh karena itu pengaruh teman sebaya 38,616 kali (OR 38,616: 95\% CI 22,516 - 66,228) lebih besar untuk mempengaruhi remaja melakukan hubungan seksual pranikah. Hal ini sesuai dengan penelitian 
(Sutriningsih et al., 2020) pengaruh teman berisiko 4,76 kali untuk melakukan perilaku seksual. Hal ini dikarenakan kelompok teman sebaya dapat mempengaruhi perilaku seksual remaja tersebut termasuk perilaku untuk melakukan hubungan seksual pranikah. Penelitian lain menyebutkan bahwa keberadaan teman sebaya yang memiliki perilaku berisiko dapat berpengaruh secara signifikan terhadap perilaku seksual pranikah pada remaja (Seferović et al., 2020).

Penelitian ini menunjukkan bahwa terdapat hubungan signifikan secara statistika antara konsumsi alkohol dengan perilaku hubungan seksual pranikah. Responden remaja yang memiliki riwayat konsumsi alkohol berpeluang 2,586 kali (OR 2,586: 95\% CI 2,586 - 1,359) untuk melakukan hubungan seksual pranikah dibandingkan dengan remaja yang tidak memiliki riwayat konsumsi alkohol. Hal ini didukung oleh penelitian yang dilakukan (Ma'Rifah \& Widada, 2019) remaja yang mengkonsumsi alkohol memiliki risiko 2,965 kali untuk melakukan hubungan seksual pranikah. Alkohol merupakan obat keras yang dapat berperan sebagai depresan sehingga dapat memperlambat aktivitas otak. Remaja yang mengkonsumsi alkohol akan terganggu dan akan berpengaruh terhadap pengendalian perilaku (Santrock \& Santrock, 2007).

Berdasarkan hasil penelitian ini, terdapat hubungan signifikan secara statistika antara sikap remaja terhadap pentingnya menjaga keperawanan dengan perilaku hubungan seksual pranikah. Kelompok remaja yang menyatakan tidak setuju terhadap sikap pentingnya menjaga keperawanan berpeluang 7,020 kali (OR 7,020: 95\% CI 4,437 - 11,106) untuk melakukan hubungan seksual pranikah dibandingkan remaja yang setuju.
Penelitian ini didukung oleh penelitian (Aarons et al., 2000) bahwa terdapat hubungan signifikan antara sikap mempertahankan keperawanan dengan penundaan perilaku hubungan seksual pada remaja. Penelitian lain yang dilakukan (Sutriningsih et al., 2020) menunjukkan bahwa remaja yang memiliki sikap tidak setuju terhadap mempertahankan keperawanan akan berisiko 2,88 kali untuk melakukan perilaku seksual berisiko tinggi sampai melakukan hubungan seksual.

Penelitian ini menunjukkan bahwa terdapat hubungan signifikan secara statistika antara usia pubertas dengan perilaku hubungan seksual pranikah. Remaja dengan usia pubertas $<15$ tahun berpeluang 0,721 kali (OR 0,721: 95\% CI 0,585 - 0,888) melakukan hubungan seksual pranikah. Hasil penelitian ini berbeda dengan penelitian (Burnett, 2019) yang menyatakan bahwa usia saat menarche pada perempuan dan saat pertama kali melakukan hubungan seksual mempunyai korelasi. Wanita yang mengalami menarche pada usia 13 tahun atau lebih muda.berisiko 2,6 kali lebih mungkin untuk melakukan hubungan seksual pertama sebelum usia 16 tahun. Hasil ini konsisten dengan penelitian remaja pria di Swedia yang mengatakan bahwa remaja pria yang mengalami mimpi basah sebelum 13 tahun memiliki lebih banyak pengalaman seksual (OR, 1,69; 95\% CI, 1,11-2,57), dan permulaan pubertas yang lebih awal dikaitkan dengan seks sebelum usia 15 tahun (OR, 3,48; 95\% CI, 2,06-5,86) 13) (Campbell et al., 2005).

Berdasarkan hasil penelitian ini, terdapat hubungan signifikan secara statistika antara perilaku berisiko dengan perilaku hubungan seksual pranikah. Remaja yang memiliki pengalaman perilaku berisiko berpeluang 17,734 kali 
(OR 17,734: 95\% CI 8,330 - 37,751) untuk melakukan hubungan seksual pranikah daripada remaja yang tidak melakukan perilaku berisiko. Hal ini didukung oleh penelitian (Ma'Rifah \& Widada, 2019) yang menunjukkan bahwa remaja yang pernah melakukan perilaku berisiko memiliki kemungkinan untuk melakukan hubungan seksual pranikah 2,736 kali lebih besar dibandingkan dengan remaja yang tidak pernah melakukan perilaku berisiko.

Pada penelitian ini, terdapat interaksi antara riwayat konsumsi alkohol dengan usia responden. remaja yang mengkonsumsi alkohol dan berusia 18 19 tahun memiliki risiko 14,14 kali untuk melakukan hubungan seksual pranikah dibandingkan dengan remaja yang tidak mengkonsumsi alkohol dan berusia 15 17. Remaja yang mengkonsumsi alkohol dan berusia 15 - 17 tahun memiliki risiko 2,586 kali untuk melakukan hubungan seksual pranikah dibandingkan dengan remaja yang tidak mengkonsumsi alkohol dan berusia 15 - 17. Remaja yang tidak mengkonsumsi alkohol dan berusia 18 19 tahun memiliki risiko 0,510 kali untuk melakukan hubungan seksual pranikah dibandingkan dengan remaja yang tidak mengkonsumsi alkohol dan berusia 15 17.

Pada penelitian ini, terdapat interaksi antara riwayat konsumsi alkohol dengan jenis kelamin. remaja yang mengkonsumsi alkohol dan berjenis kelamin pria memiliki risiko 0,48 kali untuk melakukan hubungan seksual pranikah dibandingkan dengan remaja yang tidak mengkonsumsi alkohol dan berjenis kelamin perempuan. Remaja yang mengkonsumsi alkohol dan berjenis kelamin perempuan memiliki risiko 2,588 kali untuk melakukan hubungan seksual pranikah dibandingkan dengan remaja yang tidak mengkonsumsi alkohol dan berjenis kelamin perempuan. Remaja yang tidak mengkonsumsi alkohol dan berjenis kelamin pria memiliki risiko 0,510 kali untuk melakukan hubungan seksual pranikah dibandingkan dengan remaja yang tidak mengkonsumsi alkohol dan berjenis kelamin perempuan.

Pada penelitian ini, terdapat interaksi antara usia responden dengan pengaruh teman sebaya. remaja dengan usia 18 - 19 tahun dan terpengaruh teman sebaya memiliki risiko 35,66 kali untuk melakukan hubungan seksual pranikah dibandingkan dengan remaja usia $15-17$ tahun dan tidak terpengaruh oleh teman sebaya. Remaja dengan usia 18 - 19 tahun dan tidak terpengaruh oleh teman sebaya memiliki risiko2,788 kali untuk melakukan hubungan seksual pranikah dibandingkan dengan remaja usia $15-17$ tahun dan tidak terpengaruh oleh teman sebaya. Remaja dengan usia 15 - 17 tahun dan terpengaruh oleh teman sebaya memiliki risiko 38,62 kali untuk melakukan hubungan seksual pranikah dibandingkan dengan remaja usia $15-17$ tahun dan tidak terpengaruh oleh teman sebaya.

\section{Kesimpulan}

Dari hasil penelitian ini diketahui bahwa faktor-faktor yang secara signifikan berhubungan dengan perilaku hubungan seksual pranikah pada remaja pria dan wanita usia 15 - 19 tahun di Indonesia adalah usia responden (OR 2,787: 95\% CI 1,665 - 4,665), jenis kelamin OR 0,510: 95\% CI 0,341 0,764 ), pengaruh teman sebaya (OR 38,616: $95 \%$ CI 22,516 - 66,228), konsumsi alkohol (OR 2,586: 95\% CI 2,586 - 1,359), sikap remaja terhadap pentingnya menjaga keperawanan (OR 7,020: 95\% CI 4,437 11,106), usia pubertas (OR 0,721: 95\% CI $0,585-0,888$ ) dan perilaku berisiko (OR 17,734 : 95\% CI 8,330 - 37,751). Terdapat interaksi antara riwayat konsumsi alkohol 
dengan usia responden (OR 1,963: 95\% CI 1,157 - 9,934), konsumsi alkohol dengan jenis kelamin (OR 0,364: 95\% CI 0,195 $0,679)$ dan pengaruh teman sebaya terhadap usia responden (OR 0,331: 95\% CI 0,170 $0,644)$.

\section{BIBLIOGRAFI}

Aarons, S. J., Jenkins, R. R., Raine, T. R., ElKhorazaty, M. N., Woodward, K. M., Williams, R. L., Clark, M. C., \& Wingrove, B. K. (2000). Postponing Sexual Intercourse Among Urban Junior High School Students-A Randomized Controlled Evaluation. Journal of Adolescent Health, 27(4), 236-247. Google Scholar

Badan Pusat Statistik, \& Unicef. (2016). Kemajuan Yang Tertunda: Analisis Data Perkawinan Usia Anak Di Indonesia. Unicef Indonesia, Analisis Data Perkawinan, 1-100. Google Scholar

Bkkbn. (2012). Survei Demografi Kesehatan Indonesia. In Badan Kependudukan Dan Keluarga Berencana Nasional (P. 22). Google Scholar

Bkkbn. (2017). Survei Demografi Dan Kesehatan. In Badan Kependudukan Dan Keluarga Berencana Nasional (P. 32). Google Scholar

Burnett, F. H. (2019). Frances Hodgson Burnett: The Secret Garden, A Little Princess, Little Lord Fauntleroy (Loa\# 323). Library Of America. Google Scholar

Campbell, B. C., Prossinger, H., \& Mbzivo, M. (2005). Timing of Pubertal Maturation And The Onset Of Sexual Behavior Among Zimbabwe School Boys. Archives of Sexual Behavior, 34(5), 505-516. Google Scholar

Hidayat, Z. (2005). Remaja Indonesia Dan Permasalahan Kesehatan Reproduksi.

\section{4-22. Google Scholar}

Kaplan Hi, Benjamin Js, J. A. (2010). Sinopsis Psikiatri: Ilmu Pengetahuan Perilaku Jilid 1. Bina Putra Aksara. Google Scholar

Ma'rifah, N., \& Widada, W. (2019). Pembelajaran Tai Dengan Open Ended Problem Untuk Meningkatkan Kemampuan Berpikir Kritis Mahasiswa Tadris Matematika Iain Curup. Jurnal Pendidikan Matematika Raflesia, 4(1), 1-9. Google Scholar

Mc. Murray. (2013). Community Health And Wellness: A Sociological Approach. Toronto : Mosby. Google Scholar

Nursal, D. G. A. (2008). Faktor-Faktor Yang Berhubungan Dengan Perilaku Seksual Murid Smu Negeri Di Kota Padang Tahun 2007. Jurnal Kesehatan Masyarakat Andalas, 2(2), 175-180. Google Scholar

Reproductive Health: Teen Pregnancy. (2008). From: Http://Www.Cdc.Gov. Google Scholar

Rizkianti, A., Afifah, T., Saptarini, I., \& Rakhmadi, M. F. (2020). Women's Decision-Making Autonomy In The Household And The Use Of Maternal Health Services: An Indonesian Case Study. Midwifery, 90, 102816. Google Scholar

Rusmiati, D., \& Hastono, S. P. (2015). Sikap Remaja Terhadap Keperawanan Dan Perilaku Seksual Dalam Berpacaran. Kesmas: Jurnal Kesehatan Masyarakat Nasional (National Public Health Journal), 10(1), 29-36. Google Scholar

Santrock, J. W., \& Santrock, J. W. (2007). Psikologi Pendidikan Edisi Kedua. Kencana Prenada Media Group. Google Scholar

Santrock Jw. (2007). Adolescence (11 (Ed.)). Erlangga. Google Scholar 
Faktor-Faktor yang Berhubungan dengan Perilaku Seksual Pranikah Remaja Wanita dan Pria Di Indonesia

Seferović, P. M., Coats, A. J. S., Ponikowski, P., Filippatos, G., Huelsmann, M., Jhund, P. S., Polovina, M. M., Komajda, M., Seferović, J., \& Sari, I. (2020). European Society Of Cardiology/Heart Failure Association Position Paper On The Role And Safety Of New Glucose-Lowering Drugs In Patients With Heart Failure. European Journal Of Heart Failure, 22(2), 196-213. Google Scholar
Yang Mempengaruhi Perilaku Seksual Pranikah Pada Remaja. Universitas Gadjah Mada. Google Scholar

Sutriningsih, A., Wahyuni, C. U., \& Haksama, S. (2020). Prosiding Community Health Center Resilience In Disaster Management: A Narrative Review. Google Scholar

Who. (2018). Adolescent. Google Scholar

Soetjiningsih, C. (2008). Faktor - Faktor

\section{Copyright holder:}

Nur Indah Kusuma Dewi dan Krisnawati Bantas (2021)

First publication right:

Jurnal Health Sains

This article is licensed under: 